\title{
Pharmacological profile, efficacy and safety of rupatadine in allergic rhinitis
}

\author{
Subodh Katiyara, *Shivesh Prakash ${ }^{a}$ \\ ${ }^{a}$ Department of Tuberculosis \& Respiratory diseases, GSVM Medical College, Kanpur, India
}

Received 16th October 2007; revised version received 3rd February 2008; accepted 22nd May 2008; online 12th August 2008

\begin{abstract}
Allergic rhinitis $(A R)$ is a disease with high prevalence. In $A R$, exposure to airborne allergens elicits an allergic response which involves epithelial accumulation of effector cells - e.g. mast cells and basophils - and subsequent inflammation. During the early response in AR, histamine has been found to be the most abundant mediator and it is associated with many symptoms of this disease mediated through the histamine $\mathrm{H} 1$ receptor. Therefore, anti-histamines have a role to play in the management of AR. However, the available antihistamines have certain well-known side effects like sedation and potential pro-arrythmic effects owing to their interactions with other drugs, as well as having poor or no effect on platelet activating factor (PAF) which also plays an important role in AR. This article is a qualitative systematic literature review on the pharmacological profile of rupatadine in order to evaluate its safety and efficacy in AR as compared to other anti-histamines. Rupatadine is a once-daily non-sedative, selective, long-acting $\mathrm{H} 1$ anti-histamine with antagonistic PAF effects through its interaction with specific receptors. Rupatadine significantly improves nasal symptoms in patients with AR. It has a good safety profile and is devoid of arrythmogenic effects. These properties make rupatadine a suitable first line anti-histamine for the treatment of $A R$.

(C) 2009 General Practice Airways Group. All rights reserved.

S Katiyar and S Prakash. Prim Care Resp J 2009; 18(2): 57-68.

doi:10.3132/pcrj.2008.00043
\end{abstract}

Keywords Rupatadine, allergic rhinitis, safety, efficacy, pharmacological profile

\section{Introduction}

Allergic rhinitis (AR) is a common disease, with a high prevalence ranging from about $10 \%$ for seasonal allergic rhinitis (SAR) to $10-20 \%$ for perennial allergic rhinitis (PAR). ${ }^{1}$ Besides high prevalence, $A R$ is also associated with an impaired quality of life and co-exists with co-morbidities such as atopy and asthma. ${ }^{2}$

Most studies have classified allergic rhinitis into SAR and PAR and hence this classification is being used in this review. Seasonal allergic rhinitis (SAR) is known to be triggered mostly by various types of pollens from grasses, weeds and trees as well as outdoor moulds and spores. The disease presents usually with sneezing, rhinorrhoea, nasal obstruction, pharyngeal obstruction, ocular watering and itching. ${ }^{1}$ Similar symptoms are found in PAR except that nasal obstruction is more pronounced. Most PAR patients exhibit sensitivity to one or more of the non-seasonal allergens - e.g. spores, moulds, animal dander and dust mites. ${ }^{2}$ Depending upon the spectrum of allergen sensitivities, symptoms of AR can be perennial and/or show seasonal exacerbation.

In allergic rhinitis, exposure to airborne allergens elicits an allergic response which involves epithelial accumulation of effector cells - for example, mast cells and basophils - with subsequent inflammation. Immunological activation of these effector cells is associated with secretion of pro-inflammatory mediators which include newly-formed mediators such as leukotrienes, prostaglandins and kinins and pre-formed mediators like histamine and tryptase. ${ }^{3}$ During the early response in $A R$, histamine has been found to be the most abundant mediator and has also been associated with many symptoms of this disease such as rhinorrhoea, itching, sneezing and watery eyes mediated mainly through the histamine $\mathrm{H} 1$ receptor. ${ }^{4}$

This article is a qualitative systematic literature review, undertaken to provide an insight into the pharmacological profile of rupatadine (RU) and its role in the treatment of AR. The review involves a survey of studies on RU which provide data on its side effects, safety, efficacy, and dose response

*Corresponding author: Dr Shivesh Prakash, 59 gf Sadiquabad Colony, Mankapur, Nagpur 440029, India. E-mail: shivesh_18@yahoo.com 
relationships, in order to assess whether RU offers a safer and more efficacious option for the treatment of $A R$ as compared to conventional anti-histamines which have known interactions, cardiac effects and psychomotor impairment.

\section{Methods}

\section{Criteria for study selection}

Human and animal studies and reviews on $A R$, its pathophysiology and its pharmacological profile; and studies on the effect of RU and other PAF antagonists alone and in comparison to other agents on AR were included. Studies involving evaluation of $\mathrm{RU}$ in treatment of allergic disorders other than AR were not included, except those which offered explanation regarding the mechanism of action of RU.

\section{Data sources and data extraction}

An extensive internet search was done on Medline (Ovid), EMBASE, Google, Google Scholar, OJOSE, and Trip database (allergy specialty). Key words used in different combinations were: "rupatadine," "absorption," "binding," "metabolism," "transport kinetics," "tissue distribution," "dynamics," "side effects," "clinical trial," "efficacy," "safety," "allergic rhinitis," "anti-histamines," "platelet activating factor," "cardiac effects," "cognitive effects," "psychomotor effects," "driving,". The reference section of primary studies and narrative reviews was reviewed to search for any additional primary articles that could have been overlooked by the electronic search. ${ }^{5}$ No date or language restriction was placed on the literature search. The table of contents of all issues and supplements (between 2000 and 2007) of the European Journal of Allergy and Clinical Immunology and the Journal of Allergy and Clinical Immunology were extensively searched manually for relevant studies, reviews and conference papers on RU and AR. Grey literature was not used unless there was no alternative study in the published literature.

Both the reviewers independently completed the search and checked all titles and abstracts of relevant studies maintained in Reference Manager 11.0.1, thereby avoiding duplication. The search results were reviewed and a final list of studies was prepared for full text review by both authors. The extracted data was discussed and any discrepancy resolved by including relevant information in appropriate sections of the review.

\section{The role of platelet activating factor (PAF) in allergic rhinitis}

The role of PAF in AR was demonstrated in the study on PAF antagonist $A B T-491$ in rat and guinea pig models of $A R \cdot{ }^{6,7}$ PAF induces vasodilatation and an increase in vascular permeability, which may be responsible for the appearance of

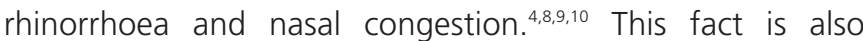

corroborated by finding that nasal fluids and plasma of patients with AR contain high levels of PAF and its metabolite lyso-PAF. ${ }^{11,12}$ Reverse transcriptase-PCR analysis of RNA from the nasal mucosa of AR patients demonstrated enhanced expression of PAF receptor mRNA. Immunohistochemical studies have demonstrated anti-PAF receptor antibodylabeled eosinophils, macrophages, neutrophils, mast cells, lymphocytes, vascular endothelial cells, epithelial cells, and submucosal glands in the nasal mucosa of these patients. ${ }^{13}$ Moreover, PAF and histamine are known to complement and promote secretion of each other. ${ }^{14,15}$

Intranasal PAF has been shown to induce nasal hyperresponsiveness. Bradykinin itself does not cause hyperresponsiveness, but is shown to be involved in the hyperresponsiveness induced by PAF in the human nasal airway. ${ }^{16}$ Endogenous PAF has also been demonstrated to play an important role in eosinophil functional responses to various exogenous stimuli, such as cytokines and immunoglobulins. ${ }^{17}$ Since PAF is synthesized, it is expected to have a major role in the late phase reaction. The effect of anti-PAF agents (WEB2086, SM10661) on the changes of nasal airway resistance (NAR) and nasal symptoms after topical antigen challenge in actively sensitised guinea pigs was studied by Narita $S$ et al. ${ }^{18}$ There was a biphasic increase in NAR after antigen challenge, with the first peak $-146.3+/-4.3 \%$ - at 10 min and the second greater peak - $163.3+/-7.8 \%$ - at 240 min after antigen challenge. Anti-PAF agents did not affect the first peak response of NAR but the late phase was significantly inhibited by anti-PAF and not by anti-histamine. The nasal symptoms, which occurred within 30 min after antigen challenge, were also significantly inhibited by anti-PAF. The results suggested that PAF activities may play an important role in the late phase. Based on these findings, it has been postulated that in the treatment of $A R$, simultaneous blockade of PAF \& histamine receptors could exhibit higher clinical efficacy than blockade of any one of these receptors. ${ }^{19}$ Some anti-histaminics have been shown to exhibit marginal PAF antagonistic properties which can not be attributed to specific interaction with PAF receptors. ${ }^{20,21}$ There is an abundance of circumstantial evidence to support the role of PAF in AR. However, more studies are required to delineate its role and to provide direct evidence particularly in humans.

\section{Rupatadine: its properties and role in allergic rhinitis}

Rupatadine (RU) (see Figure 1) is a novel drug which exhibits both anti-histamine and anti-PAF effects through its interaction with specific receptors. ${ }^{22}$ Its chemical designation is 8-chloro-11-[1-[(5methyl-3-pyridinyl)methyl]piperidin-4-ylidene]-6,11-dihydro-5Hbenzo[5,6]cyclohepta[1,2-b] pyridine fumarate. The empirical formula is $\mathrm{C}_{26} \mathrm{H}_{26} \mathrm{CIN}_{3}$ and molecular weight is $415.958 \mathrm{~g} / \mathrm{mol}$. 
Figure 1. Molecular structure of Rupatadine fumarate.

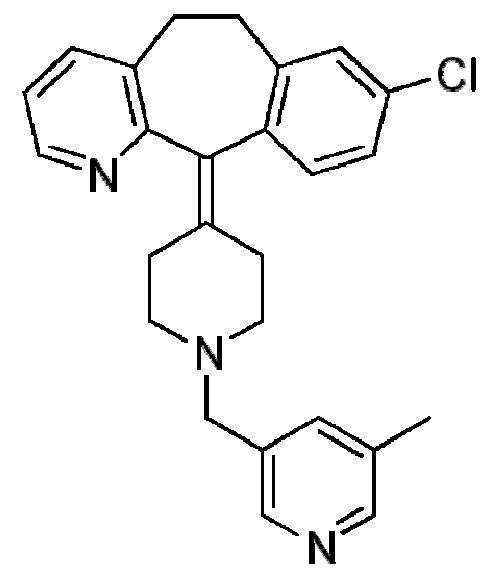

\section{Pharmacokinetic properties}

1. Absorption: Rapid absorption has been found in all species including mice, rats, dogs, monkeys and humans, with $T_{\max }$ in humans being 0.75 to 1 hour. ${ }^{22}$ The $C_{\max }$ after $10 \mathrm{mg}$ in single and repeated doses are 2.2 and $2.0 \mathrm{ng} / \mathrm{ml}$, respectively. The rapid absorption of $\mathrm{RU}$ correlates with the onset of anti-histamine and anti-PAF actions following exposure to an allergen as assessed by wheal and flare inhibition, which occurs within 1-2 hours after drug intake. Oral bio-availability has been shown to be more than $50 \%$ with its half life (t $1 / 2$ ) ranging from 1 hour (mice) to $2-3$ hours (rats and dogs). ${ }^{23}$ Human studies with RU have shown the mean $\mathrm{t} 1 / 2$ in healthy human volunteers to be $\sim 6$ hours (range 4.3-14.3 hours). ${ }^{22}$ The $C_{\max }$ and AUC increased in proportion to the dose with a dosage of $<40 \mathrm{mg} /$ day, whereas clearance and $t / 2$ remained constant.

2. Metabolism: Oxidative processes, namely oxidation of pyridine methyl group to the carboxylic acid, $\mathrm{N}$-dealkylation of the piperidine nitrogen and hydroxylation in the 3, 5 and 6 positions in the tricyclic ring system are the main biotransformation pathways of RU. Conjugates with glucoronic acid are also found. Some of the metabolites retain anti-histaminic activity and partially contribute to the overall efficacy of the drug and the long duration of action. ${ }^{23}$ CYP3A4 was identified in vitro as the main isoenzyme responsible for the biotransformation of $\mathrm{RU}$ and genetic polymorphism in its biotransformation is unlikely. ${ }^{24,25}$

3. Distribution: RU is $98-99 \%$ bound to the human plasma proteins. This high degree of binding does not cause the compound to be retained in the circulating blood and it is well distributed in other tissues allowing it to reach its target receptor. Its plasma concentration is far lower than would be expected to saturate plasma binding capacity - hence RU displacement from its binding sites when co-administered with other drugs is unlikely. ${ }^{25}$

4. Excretion: The plasma concentration follows a biexponential drop with a mean elimination $\mathrm{t} 1 / 2$ of 5.9 hours. Biliary excretion is the most important route of elimination. In a study on humans using radio-labeled RU (14 C-RU $40 \mathrm{mg}), 34.6 \%$ of the radio-activity administered was recovered in urine and $60.9 \%$ in faeces collected over seven days. RU undergoes considerable pre-systemic metabolism when administered orally, and hence the amounts of unaltered active substance found in faeces and urine are very low. ${ }^{25}$

5. Drug and food interactions: Table 1 summarises the various drug and food interaction of RU. Though coadministration with ketoconazole or erythromycin did not result in any adverse event - including any changes in ECG parameters such as the QTc interval, changes in laboratory tests or vital signs - co-administration with ketoconazole, erythromycin (or any other potential inhibitors of CYP3A4) is not advised due to a marked increase in its concentration. As shown in the table, the combination of $\mathrm{RU}$ with azithromycin or fluoxetine is well tolerated and may be coadministered safely at therapeutic doses. Fluoxetine is known to inhibit some P450 cytokines such as CYP2D6, CYP3A426.

6. Elderly population: The mean $t 1 / 2$ of $R U$ in elderly subjects is $8.7 \mathrm{~h}$ against $5.9 \mathrm{~h}$ in younger volunteers, perhaps due to a physiological decrease in pre-systemic metabolism. However, since no adverse effects of delayed clearance were noticed, and given that the $10 \mathrm{mg}$ dose was well tolerated by the elderly volunteers, it is not necessary to make any adjustments for elderly patients, at least at this dose. ${ }^{22,23,25}$

\section{Pharmacodynamic properties}

Rupatadine is an anti-allergic drug with other benefits such as inhibition of mast cell degranulation, neutrophil and eosinophil migration and cytokine release. ${ }^{29,30}$ It exhibits strong antagonistic activity towards both histamine $\mathrm{H} 1$ and PAF receptors. ${ }^{19}$

Anti-histaminic and anti-PAF effects were studied using its ability to inhibit flare and wheals produced by intradermal injection of histamine and PAF, respectively. ${ }^{31,32}$ The specific inhibition of PAF was determined in blood using the ex vivo platelet aggregation test. ${ }^{19}$ These studies also included a nasal challenge test with a specific allergen in atopic volunteers.

\section{Anti-histaminic activity}

Rupatadine has a high affinity for the $\mathrm{H} 1$ receptor. Using the guinea-pig ileum functional test, the anti-histaminic activity of RU was compared with other first and second generation antihistaminics. ${ }^{19} \mathrm{RU}$ was more active than terfenadine, loratadine, cetirizine, hydroxyine and diphenhydramine. RU and 
Table 1. Drug and food interactions of Rupatadine.

\begin{tabular}{|c|c|c|c|}
\hline Study ref. & Drug interaction & Effect studied & Findings \\
\hline 26 & $\begin{array}{l}\text { Rupatadine } 20 \mathrm{mg}- \\
\text { Ketoconazole } 200 \mathrm{mg} / \text { day }\end{array}$ & $\begin{array}{l}\text { Metabolic drug - drug } \\
\text { interaction }\end{array}$ & $\begin{array}{l}\text { Ketoconazole inhibited both pre-systemic and systemic } \\
\text { metabolism of Rupatadine, and increased the AUC of unchanged } \\
\text { drug by about } 10 \text { fold and decreased the AUC of metabolites }\end{array}$ \\
\hline 26 & $\begin{array}{l}\text { Rupatadine } 20 \mathrm{mg}- \\
\text { Erythromycin } 500 \mathrm{mg} / \text { day }\end{array}$ & $\begin{array}{l}\text { Metabolic drug - drug } \\
\text { interaction }\end{array}$ & $\begin{array}{l}\text { Erythromycin increased the AUC of unchanged drug by } 2-3 \\
\text { folds without increasing significantly elimination } t 1 / 2 \text { and systemic } \\
\text { exposure of metabolites. Despite this increase in the plasma conc. } \\
\text { of Rupatadine no adverse event was observed including any ECG } \\
\text { parameter like QTc interval, laboratory tests, and vital signs. }\end{array}$ \\
\hline 23 & $\begin{array}{l}\text { Rupatadine } 10 \mathrm{mg}- \\
\text { Azithromycin }\end{array}$ & $\begin{array}{l}\text { Metabolic drug - drug } \\
\text { interaction }\end{array}$ & $\begin{array}{l}\text { No clinically relevant alterations in the pharmacokinetic } \\
\text { parameters of Rupatadine and active metabolites were observed. }\end{array}$ \\
\hline 23 & $\begin{array}{l}\text { Rupatadine } 20 \mathrm{mg}- \\
\text { Fluoxetine }\end{array}$ & $\begin{array}{l}\text { Metabolic drug - drug } \\
\text { interaction }\end{array}$ & $\begin{array}{l}\text { No clinically relevant alterations in the pharmacokinetic } \\
\text { parameters of Rupatadine and active metabolites were observed. }\end{array}$ \\
\hline 23 & $\begin{array}{l}\text { Rupatadine } 10 \mathrm{mg} \\
\text { Rupatadine } 10 \mathrm{mg}- \\
\text { Lorazepam }\end{array}$ & Sedation and mental ability & $\begin{array}{l}\text { Does not impair mental ability and does not potentiate } \\
\text { Lorazepam induced mental impairment }\end{array}$ \\
\hline 27 & $\begin{array}{l}\text { Rupatadine - grape fruit } \\
\text { juice }\end{array}$ & $\begin{array}{l}\text { Metabolic drug - food } \\
\text { interaction }\end{array}$ & $\begin{array}{l}\text { Grape fruit juice inhibits pre-systemic metabolism of Rupatadine, } \\
\text { increasing the AUC of unchanged drug approximately threefold, } \\
\text { without significant increases of systemic AUC of the two } \\
\text { metabolites }\end{array}$ \\
\hline 28 & Rupatadine - food & Drug - food & $\begin{array}{l}\text { Intake of food significantly increases the AUC of Rupatadine. The } \\
\text { exposure to metabolites was virtually the same. The } T_{\max } \text { of } \\
\text { Rupatadine was delayed by } 1 \text { hour and } C_{\max } \text { was not affected by } \\
\text { food intake. Later differences had no clinical significance }\end{array}$ \\
\hline
\end{tabular}

desloratadine show similar anti-histaminic activity in vitro (binding assay Kiapp=26 and 22 nM; RU and desloratadine, respectively). Some of the $\mathrm{RU}$ metabolites also exhibit antihistaminic activity in vitro.

Peripheral anti-histaminic activity of RU was assessed by the percentage inhibition of flares and wheals induced by histamine pricks. $^{33}$ All RU doses (10, 20, 40, 80 mg) gave significantly different results as compared to placebo within 96 hours. The duration of wheal and flare suppression areas was dose-related. The long-lasting effect may be due to some metabolites. Low doses - i.e. 2 and $5 \mathrm{mg}$ - showed percentage inhibition of approximately $50 \%$ in healthy volunteers. The percentage inhibition rose to $60 \%$ and lasted until 24 hours post $10 \mathrm{mg}$ dose of RU. A potent and prolonged inhibitory effect was demonstrated with the $20 \mathrm{mg}$ dose; a maximum inhibition of $71 \%$ was achieved and it remained above $45 \%$ until 72 hours.

\section{Platelet activating factor antagonist activity}

The PAF antagonistic activity of RU was documented using inhibition of platelet aggregation in rabbit platelet-rich plasma, washed platelets and dog whole blood, with $\mathrm{IC}_{50}$ (inhibitory conc. of $50 \%$ ) values of $2.9,0.2$, and $0.29 \mathrm{mM}$ respectively. The in vitro inhibition shown by $\mathrm{RU}$ was lower than that of a selective PAF antagonist (WEB-2086). However, the inhibition was much greater than second generation anti-histaminics, which display little or no PAF antagonist activity. Dual effect i.e. both anti-histamine and PAF antagonistic effect - was demonstrated by RU on histamine- or PAF-induced bronchospasm in a guinea pig model. This dual effect was not seen with loratadine or WEB 2086 - which is to be expected since the latter is selective for PAF and loratadine has a negligible action on $\mathrm{PAF}^{19}$ Loratadine and cetirizine inhibit only histamine-induced wheal, while RU has been demonstrated to inhibit PAF-induced reactions as well. ${ }^{34}$ In an animal model of conjunctivitis in guinea pigs, induced by histamine and PAF, it was observed that RU applied as eye lotion was approximately 10 times more powerful than loratadine against histamineinduced conjunctivitis, and, unlike RU, loratadine had no effect on PAF-induced conjunctivitis. ${ }^{35}$ The maximum effect of RU occurs after four hours, and significant effects are observed even after 24 hours following single dose, indicating a longlasting effect. It has been demonstrated that on increasing the dose of RU the extent of maximum inhibition of wheal and flare reaction not only increases but is also achieved earlier and the effect maintained for longer. The dose response relationship of 
Table 2. Dose response relationship of Rupatadine on inhibition of wheal and flare induced by PAF.

\begin{tabular}{|c|c|c|c|c|c|}
\hline \multirow{2}{*}{$\begin{array}{l}\text { Dose of } \\
\text { Rupatadine }\end{array}$} & \multicolumn{2}{|c|}{ Early inhibition } & \multicolumn{2}{|c|}{ Maximum inhibition } & \multirow[t]{2}{*}{ Remarks } \\
\hline & Extent & $\begin{array}{l}\text { Time taken to } \\
\text { achieve (hrs) }\end{array}$ & Extent & $\begin{array}{l}\text { Time taken to } \\
\text { achieve (hrs) }\end{array}$ & \\
\hline $10 \mathrm{mg}$ & -- & -- & $41 \%$ & 24 & -- \\
\hline $20 \mathrm{mg}$ & $42 \%$ & 6 & $56 \%$ & 24 & Maintained up to 48 hours \\
\hline $40 \mathrm{mg}$ & $68 \%$ & 4 & $87 \%$ & 6 & Retained above $60 \%$ until 72 hours \\
\hline $80 \mathrm{mg}$ & $91 \%$ & 4 & $93 \%$ & 48 & Effect evident even at 96 hours post dose \\
\hline
\end{tabular}

RU on inhibition of wheal and flare induced by PAF is summarised in Table $2 .^{33}$ The efficacy of RU increases linearly with increasing dose up to 40mg, beyond which the dose increments are associated with far smaller increments in efficacy.

\section{Anti-cholinergic effects}

Many of the first generation anti-histaminics are known to have anti-cholinergic effects. No anti-cholinergic effects were seen with $\mathrm{RU}$ at single doses in the dose range $10-80 \mathrm{mg}$ in humans. ${ }^{33}$

These studies clearly demonstrate that: 1) RU exhibits dual effect (anti-platelet and anti-histaminic) in vivo; 2) the antihistamine effect is equal to or greater than that of other antihistamines; and 3) it is the only anti-histaminic compound which has significant PAF antagonist activity.

\section{Wide spectrum anti-inflammatory action}

$\mathrm{RU}$ shows potent anti-allergic activity in vitro and in vivo in various type I hypersensitivity models (mast cell degranulation and eosinophil chemotaxis inhibition). Efficacy in non-histamine dependent pharmacological models such as those involving endotoxin challenge and models of type III hypersensitivity reaction can probably be due to its PAF antagonistic activity. In the early phase response of the allergic process, the effector cells are mast cells which play an important role. RU has been shown to inhibit mast cell degranulation induced by nonimmunological stimuli (compound 48/80 and calcium ionophore A23187) in rat peritoneal mast cells and also immunological stimuli (Ascaris) in isolated skin mast cells from sensitised dogs. ${ }^{36} \mathrm{RU}$ also reduced tumour necrosis factor release from canine skin mast cells and in the human mast cell line HMC-1. ${ }^{29,37}$

In the allergic late phase response, the eosinophils and lymphocytes are important effector cells. In actively-sensitised guinea pigs challenged with antigen, RU inhibited the eosinophil recruitment in the bronchoalveolar lavage fluid. ${ }^{38}$ It has been shown that eosinophils from allergic volunteers exhibited a markedly increased sensitivity in their chemotactic response toward PAF compared with eosinophils from normal donors. $^{39}$ PAF is a potent stimulus for human eosinophil chemotaxis which is inhibited by PAF receptor antagonists. ${ }^{40}$ Rupatadine's potent PAF antagonistic activity represents the likely mechanism behind its inhibition of eosinophil chemotaxis. $\mathrm{RU}$ has also been shown to inhibit the production of inflammatory cytokines after in vitro activation of human $T$ cells especially Th2 cytokine IL-5. ${ }^{41}$

It is known that most of the anti-inflammatory effect of an anti-histaminic is produced in a histamine receptor-dependent manner. On the contrary, RU has been shown to inhibit the activity of transcription factor AP-1 both dependently and independently from the $\mathrm{H} 1$ receptor. Owing to its high affinity for the $\mathrm{H} 1$ receptor $\left(\mathrm{K}_{1} 1.6 \mathrm{nM}\right)$, it inhibits the histamineinduced IL-6 and IL-8 production at concentrations that are below the plasma levels reached at therapeutic dose. ${ }^{41}$

$\mathrm{RU}$ strongly inhibits hypersensitivity reactions in vivo, including both active and passive anaphylaxis in several species. It displays strong inhibitory activity in models of increased vascular permeability induced by antigen in sensitised beagle dogs. ${ }^{19}$ The duration of action was prolonged ( $>24$ hours at $1 \mathrm{mg} / \mathrm{kg}$ P.O.) and parallel to those observed in studies in which histamine was injected intradermally in dogs ${ }^{34}$

In conclusion, rupatadine shows anti-inflammatory and anti-allergic profiles in various allergy models, tested in various species, both in vitro and in vivo, and in healthy and atopic individuals.

\section{Safety profile}

A total of 3490 patients or healthy volunteers have been exposed to rupatadine in clinical studies. The adverse effects in 2025 subjects exposed to RU $10 \mathrm{mg}$ in controlled clinical trials are summarised in Table $3 .^{42}$ There is a dearth of evidence on the long-term (> 1 year) safety profile of RU in perennial allergic rhinitis. In a long-term uncontrolled study, 120 patients with persistent AR were exposed to RU for 12 months to evaluate its long-term safety according to European Medicine Agency guidelines. ${ }^{43}$ The more frequent treatment-related adverse effects during this period were somnolence (6\%) and headache, dry 


\begin{tabular}{|c|c|c|c|c|}
\hline \multirow[t]{3}{*}{ Adverse events } & \multicolumn{4}{|c|}{ Treatment } \\
\hline & \multicolumn{2}{|c|}{ Rupatadine 10 mg ( $n=2025)$} & \multicolumn{2}{|c|}{ Placebo ( $n=1315)$} \\
\hline & $\mathrm{n}$ & $\%$ & $\mathrm{n}$ & $\%$ \\
\hline Somnolence & 192 & 9.5 & 45 & 3.4 \\
\hline Headache & 139 & 6.8 & 74 & 5.6 \\
\hline Fatigue & 64 & 3.2 & 26 & 2 \\
\hline Dizziness & 21 & 1 & - & - \\
\hline Asthenia & 30 & 1.5 & - & - \\
\hline Dry mouth & 24 & 1.2 & - & - \\
\hline
\end{tabular}

mouth, fatigue and rash ( $<1 \%)$. No relevant ECG findings or lab abnormalities were evidenced throughout the study. This study confirmed the good long-term safety profile of RU.

\section{Cardiac safety}

A prolonged QTC interval on the ECG is a feature that has been associated with drug-induced Torsades De Pointes (TDP), a potentially fatal polymorphic ventricular tachyarrhythmia identified by the continuously twisting appearance of the QRS complex in the 12-lead ECG.

In recent years, there has been a concern about the cardiotoxicity of non-sedating anti-histamines, with reports of TDP first with astemazole and later with terfenadine. The initial belief that cardiotoxicity was a class effect of non-sedating antihistamines proved unfounded, since fexofenadine, the active metabolite that mediates the anti-histamine actions of terfenadine, does not seem to have these cardiotoxic effects. A dose of RU more than 100 times the clinically recommended dose of $10 \mathrm{mg}$ neither extended the QTC or QRS intervals nor did it produce arrhythmia in various species of animals such as rats, guinea pigs, and dogs. ${ }^{44} \mathrm{RU}$ and its main active metabolite in humans, 3-hydroxy desloratadine, does not affect cardiac action potential and isolated dog Purkinje fibres at concentrations >2000 times greater than the $C_{\max }$ reached after the administration of RU $10 \mathrm{mg}$ in humans. In a study that evaluated the effect on cloned human HERG channels, RU inhibited the channel at a concentration of 1685 times greater than the $C_{\max }$ obtained after the administration of $10 \mathrm{mg}$ RU. A distribution study shows that it has no cardiac tropism, showing low cardiac tissue levels that are not even detectable at 24 hours after administration. ${ }^{44}$ It has been demonstrated that the new generation of $\mathrm{H} 1$ receptor antagonists blocked several cardiac potassium $\left(\mathrm{K}^{+}\right)$currents. ${ }^{45}$ Moreover, it has been shown that they block hKv1.5 channels cloned from human heart and expressed in mammalian cell lines. ${ }^{46}$ These channels are the counterpart of the ultra-rapid delayed rectifier current which is involved in the control of duration of atrial action potentials in the human heart. ${ }^{47}$ Caballero et al. studied the effects of RU on human cloned hKv1.5 channels expressed in Ltk- cells using the wholecell patch-clamp technique. ${ }^{48}$ They demonstrated that RU blocked hKv1.5 channels in a concentration-, time-, and voltagedependent manner. $C_{\max }$ achieved in healthy volunteers after oral administration of RU $20 \mathrm{mg}$ per day is $5.5 \mathrm{nM}^{49}$ This study indicated that these $C_{\max }$ values were almost 400 -fold below the $K_{D}$ for hKv1.5 block. Therefore, a pro-arrhythmic effect of RU due to blockade of this human $\mathrm{K}^{+}$channel is not expected. Recently a study by Hove-Madsen et al. revealed that the proarrhythmic anti-histaminic drug terfenadine alters intracellular calcium handling in isolated human atrial myocytes. Terfenadine also inhibits the L-type calcium current, significantly increases the spontaneous $\mathrm{Na}-\mathrm{Ca}$ exchange current frequency and spontaneous calcium release from the sarcoplasmic reticulum. These effects were not seen with RU..$^{50}$

In accordance with guideline recommendation ICH E14, June 2004, ${ }^{51}$ a thorough QT/QTC study was performed in order to determine whether or not RU has a threshold pharmacological effect on cardiac repolarization, as detected by QT/QTC interval prolongation.52 The validity of the trial was demonstrated by the fact that moxifloxacin, the positive control group, demonstrated the expected change in QTc duration. The ECG data for RU at both 10 and $100 \mathrm{mg}$ did not reveal any effect. There was no gender effect, pharmacodynamic relation of RU and its main metabolites, or imbalance in the outliers, which also confirms the lack of any effect of RU specifically on QTtc duration. This study demonstrated that RU, at even 10 times the therapeutic dose, does not have any pro-arrhythmic side effects.

\section{Central nervous system, cognitive and psychomotor effects}

Even at high doses $(100 \mathrm{mg}$ and $10 \mathrm{mg} / \mathrm{kg}$ orally in mice and cynomolgus monkey, respectively) RU has not been found to 
cause any behavioural changes. In a study on guinea pigs, $\mathrm{H} 1$ receptor occupancy was studied in lungs and the central nervous system (CNS) - specifically the cerebellum. ${ }^{19}$ RU was administered at doses comparable to those used in humans and this ensured effective blockade of $\mathrm{H} 1$ receptors in the lungs. At these doses, in spite of effective blockade of $\mathrm{H} 1$ receptors in the lung, there was almost no $\mathrm{H} 1$ receptor blockade found in the CNS. This phenomenon was also seen with loratadine (a nonsedating anti-histamine) but not with hydroxyzine (a first generation anti-histamine). ${ }^{33}$ Barbanoj et al. assessed the CNS activity of single increasing doses of $\mathrm{RU}$ in comparison with hydroxyzine and placebo in a crossover, randomised, doubleblind, placebo-controlled study; treatments tested were RU 10, 20, 40 and $80 \mathrm{mg}$ and hydroxyzine $25 \mathrm{mg}$, as a positive standard. CNS effects were obtained by objective tests of psychomotor performance and subjective mood scales. The study revealed significant impairment, of a similar magnitude, after hydroxyzine $25 \mathrm{mg}(p=0.01)$ and RU $80 \mathrm{mg}(p=0.02)$, while therapeutically-relevant lower doses of RU (10 and 20 mg) were similar to placebo. ${ }^{33}$ Another study by Barbanoj et al. assessed the effects of alcohol $0.8 \mathrm{~g} / \mathrm{Kg}$ on RU-associated CNS effects with doses of 10 and 20mg. Seven psychomotor performance tests (finger tapping, fine motor skills, nystagmus, temporal estimation, critical-flicker-fusion frequency, d2 cancellation, simple reaction) and 11 subjective self-reports (drunkenness, sleepiness, alertness, clumsiness, anger, inattentiveness, efficiency, happiness, hostility, interest and extraversion) were carried out. Results showed that single oral doses of RU $10 \mathrm{mg}$ in combination with alcohol do not produce more cognitive and psychomotor impairment than alcohol alone. It was concluded that higher doses of $\mathrm{RU}$, in combination with alcohol, may induce cognitive and psychomotor deterioration similar to hydroxyzine and cetirizine, even at therapeutic doses. ${ }^{53}$

The effects of $R U$ on driving were evaluated in a study performed on healthy human volunteers, and was compared with $50 \mathrm{mg}$ hydroxyzine or placebo. ${ }^{54}$ Driving performance was assessed using a standard highway test, standard deviation of the lateral position, Stanford sleepiness scale, driving quality scale and rate of sedation. There was no difference between RU and placebo, whereas driving performance was impaired by hydroxyzine. The non-significant effects of $\mathrm{RU}$ on driving performance has also been highlighted by Jáuregui et al..$^{55}$

In conclusion, as regards CNS side effects, RU behaves similarly to second generation anti-histamines, and is nonsedative.

\section{Clinical studies on rupatadine in allergic rhinitis}

The efficacy of rupatadine as a treatment for allergic rhinitis has been investigated in several international, randomised, double- blind, multi-centre trials. The target study population was patients suffering from moderate to severe $A R$ - as documented by clinical records - for at least two years. Patients were required to score $>5$ points for nasal symptoms in a standardised scale at inclusion, in order to recruit patients in the acute stage of the disease; in addition, this also ensured that only patients suffering from acute episodes of at least mild intensity would be included.

The main efficacy variables in these studies were based on daily subjective assessment of symptom severity recorded by patients in their diary. Overall efficacy impression was calculated from the score assigned by both the investigator and the patient in all studies according to the conventional scale.

The main efficacy variables were:

1) Mean daily total symptom score (DTSSm) - the main variable in the SAR studies. This is the mean of the daily symptom scores recorded for each of the assessed symptoms. $^{56}$

2) The percentage of days with a severity symptom score $<1$ (PDmax) for each patient - the main variable in the PAR studies. . $^{57}$

3) Mean daily symptom score (DSSm); a secondary variable the mean of all the scores recorded for a given symptom per patient and for all the study days.

\section{Seasonal allergic rhinitis}

All doses of RU have been shown to be more effective than placebo in alleviating the symptoms of SAR in a dosedependent manner. ${ }^{58} \mathrm{~A}$ summary of clinical trials covering the indications for the treatment of SAR is provided in Table 4.

Rupatadine 10 and $20 \mathrm{mg}$ were superior $(p<0.05)$ at improving nasal and ocular symptoms of SAR in comparison with placebo. Except for a general trend towards quicker relief of symptoms with RU $20 \mathrm{mg}$ after one week of treatment, no significant differences were detected between RU 10 and $20 \mathrm{mg}^{58}$

Rupatadine $10 \mathrm{mg}$ once daily was compared to ebastine 10 mg once daily and placebo. ${ }^{59}$ Significant differences were detected in DTSSm between RU treatment and placebo (33\% lower for RU group; $\mathrm{p}=0.005)$ after two weeks of treatment. Total symptom scores were $22 \%$ lower for RU than for ebastine; however, this could not reach statistical significance. In the symptom by symptom scores analysis, RU was superior to ebastine and placebo. As compared to placebo, RU reduced the severity of all symptoms with a statistically significant reduction found in sneezing, rhinnorhoea, lacrimation, and nasal itching. The greatest difference between active treatments and placebo was for rhinnorhoea (RU versus placebo, $p<0.001$; ebastine versus placebo, $p<0.005$ ).

The efficacy of RU and cetirizine was compared at $10 \mathrm{mg} /$ day for two weeks in SAR patients. ${ }^{60}$ Both groups had similar responses in terms of mean DTSSm values. However, 
Table 4. Summary of efficacy of Rupatadine in adults and adolescents (aged > 12 years) with seasonal allergic rhinitis.

\begin{tabular}{|c|c|c|c|c|c|}
\hline Ref & Study design & $\begin{array}{l}\text { RU dose and } \\
\text { comparative } \\
\text { treatment }\end{array}$ & $\begin{array}{l}\text { Treatment } \\
\text { duration }\end{array}$ & $\begin{array}{l}\text { Number of } \\
\text { patients } \\
\text { (randomized/ } \\
\text { treated) }\end{array}$ & $\begin{array}{l}\text { Efficacy } \\
\text { results } \\
\text { (DTSSm) }\end{array}$ \\
\hline 58 & $R, D B, P C$ & $\begin{array}{l}10 \mathrm{mg} \\
20 \mathrm{mg}\end{array}$ & 2 weeks & $178 / 174$ & $\begin{array}{l}\text { RU } 10 \text { vs PL* } \\
R U 20 \text { vs } P^{*}\end{array}$ \\
\hline 26 & $R, D B, P C$ & $\begin{array}{l}2.5 \mathrm{mg} \\
5 \mathrm{mg} \\
10 \mathrm{mg} \\
20 \mathrm{mg}\end{array}$ & 2 weeks & 395/392 & $\begin{array}{l}\text { Ru } 2.5 \text { vs pl* } \\
\text { Ru } 5 \text { vs pl* } \\
\text { Ru } 10 \text { vs pl* } \\
\text { Ru } 20 \text { vs pl* }\end{array}$ \\
\hline 59 & $R, D B, P C$ & $\begin{array}{l}10 \mathrm{mg} \\
\mathrm{EBA}(10 \mathrm{mg})\end{array}$ & 2 weeks & $250 / 243$ & $\begin{array}{l}\text { RU } 10 \text { vs PL* } \\
\text { EBA vs PL ns }\end{array}$ \\
\hline 60 & $R, D B$ & $\begin{array}{l}10 \mathrm{mg} \\
20 \mathrm{mg} \\
\text { CTZ }\end{array}$ & 2 weeks & $373 / 362$ & $\begin{array}{l}\text { RU } 10 \text { vs CTZ ns } \\
\text { RU } 20 \text { vs CTZ ns }\end{array}$ \\
\hline 61 & $R, D B$ & $\begin{array}{l}10 \mathrm{mg} \\
20 \mathrm{mg} \\
\text { LOR (10mg) }\end{array}$ & 2 weeks & $339 / 339$ & $\begin{array}{l}\text { RU10 vs LOR ns } \\
\text { RU20 vs LOR ns* }\end{array}$ \\
\hline
\end{tabular}

R: randomised, DB: double blinded, PC: placebo controlled, RU: Rupatadine, CTZ: cetirizine, PL: placebo, LOR: Loratadine

* $p<0.05$

evaluation of overall efficacy at day 7 revealed that $93.3 \%$ patients in the RU group and $83.7 \%$ patients in the cetirizine group showed significant improvement $(p=0.022)$ The study suggested a faster effect of RU, since $81.1 \%$ of patients on RU had insignificant or absent symptoms of runny nose versus $68.6 \%$ in the cetirizine group.

The efficacy of RU at 10 and $20 \mathrm{mg}$ was evaluated against loratadine $10 \mathrm{mg}$ over two weeks in SAR patients. ${ }^{61} \mathrm{RU}$ was more effective than loratadine at both doses. Patients on RU demonstrated scores for sneezing and nasal itching which were significantly lower than those observed in patients on loratadine.

A recent trial was performed to evaluate the efficacy of RU $10 \mathrm{mg} /$ day and placebo on allergen-induced symptoms (including nasal congestion), nasal airflow, nasal secretion and subjective tolerability in response to grass pollen in a controlled allergen exposure chamber. ${ }^{62}$ In a randomised double-blind placebo-controlled trial, 45 subjects with a history of SAR received $\mathrm{RU}$ or placebo every morning for eight days for two subsequent periods which were separated by a 14-day washout interval. On day 8 of each crossover period, subjects underwent a 6-hour allergen exposure in the exposure chamber in which a constant and homogenous concentration of aeroallergens was maintained. Subjective and objective assessments were performed online during the exposure. Subjective single and composite nasal and non-nasal symptoms were consistently less severe with RU than placebo, starting from assessment time up to $15 \mathrm{~min}$ before the end of the 6-hour allergen challenge, with the most significant effects seen for nasal rhinnorhoea, nasal itching, sneezing attacks, and total nasal symptoms (all $\mathrm{p}<0.0001$ ). All other symptoms including nasal congestion were also significantly reduced with the active treatment compared to placebo. The results suggest that, in patients with allergeninduced SAR, RU significantly reduced nasal and non-nasal symptoms as well as nasal secretion and subjective complaints, as compared with placebo. RU showed a rapid onset of action as indicated by statistically lower total nasal symptom score values compared with placebo, which were observed already at the first assessment time during controlled allergen exposure (15 min. $p=0.001$ ).

\section{Perennial allergic rhinitis}

Studies on the efficacy of rupatadine in PAR are summarised in Table 5. A dose-ranging placebo-controlled study demonstrated that RU 10 and $20 \mathrm{mg}$ provided better efficacy than placebo. However, the dose relationship was not established in this trial. ${ }^{26,64}$ The study compared RU at doses 10 and 20mg, loratadine $10 \mathrm{mg}$, and placebo. Results showed that the mean PDmax over 28 days' treatment duration for RU and loratadine were consistently better than those for placebo (34.1\%). Superior mean PDmax values were observed for RU $20 \mathrm{mg}$ (50.4\%) which was slightly higher than that for RU $10 \mathrm{mg}$ $(48.7 \%)$ and loratadine $10 \mathrm{mg}(48.6 \%)$. Statistically significant 
Pharmacological profile, efficacy and safety of rupatadine in allergic rhinitis

Table 5. Summary of efficacy of Rupatadine in adults and adolescents (aged $>12$ years) with perennial allergic rhinitis.

\begin{tabular}{|c|c|c|c|c|c|}
\hline Ref & Study design & $\begin{array}{l}\text { RU dose and } \\
\text { comparative } \\
\text { treatment }\end{array}$ & $\begin{array}{l}\text { Treatment } \\
\text { duration }\end{array}$ & $\begin{array}{l}\text { Number of } \\
\text { patients } \\
\text { (randomized/ } \\
\text { treated) }\end{array}$ & $\begin{array}{l}\text { Efficacy } \\
\text { results } \\
\text { (DTSSm) }\end{array}$ \\
\hline 26,64 & $R, D B, P C$ & $\begin{array}{l}10 \mathrm{mg} \\
20 \mathrm{mg}\end{array}$ & 4 weeks & $248 / 245$ & $\begin{array}{l}R U 10 \text { vs PL* } \\
R U 20 \text { vs PL* }\end{array}$ \\
\hline 26,64 & $R, D B, P C$ & $\begin{array}{l}10 \mathrm{mg} \\
20 \mathrm{mg} \\
\text { LOR 10mg }\end{array}$ & 4 weeks & $283 / 283$ & $\begin{array}{l}\text { RU } 10 \text { vs } P^{*} \\
R U 20 \text { vs } P^{*} \\
\text { LOR vs } P^{*}\end{array}$ \\
\hline 26,64 & $R, D B, P C$ & $\begin{array}{l}10 \mathrm{mg} \\
\text { EBA } 10 \mathrm{mg}\end{array}$ & 4 weeks & $223 / 219$ & $\begin{array}{l}\text { RU } 10 \text { vs } P^{*} \\
\text { EBA vs } \mathrm{PL}^{*}\end{array}$ \\
\hline 26,64 & $R, D B, P C$ & $\begin{array}{l}10 \mathrm{mg} \\
20 \mathrm{mg} \\
\text { CTZ 10mg }\end{array}$ & 4 weeks & $282 / 273$ & $\begin{array}{l}\text { RU } 10 \text { vs PL* } \\
\text { RU } 20 \text { vs PL* } \\
\text { CTZ vs PL }\end{array}$ \\
\hline 63 & $R, D B, P C$ & $\begin{array}{l}10 \mathrm{mg} \\
\text { CTZ 10mg }\end{array}$ & 12 weeks & $543 / 542$ & $\begin{array}{l}\text { RU } 10 \text { vs } P L^{*} \\
\text { CTZ vs PL ns }\end{array}$ \\
\hline
\end{tabular}

differences for mean PDmax were only detected between RU $20 \mathrm{mg}$ and placebo. According to DTSSm values the two active treatments with RU and loratadine were superior to placebo, reaching statistical significance in all three active treatment groups. RU produced a greater reduction in symptom severity compared with placebo in five symptoms, of which rhinnorhoea, sneezing and conjunctival itching were statistically significant, whilst differences between loratadine and placebo were statistically significant only for rhinnorhoea and nasal itching.

Another study compared RU $10 \mathrm{mg}$, ebastine $10 \mathrm{mg}$ and placebo to evaluate the efficacy and safety of $R U$ in the treatment of PAR over 28 days' duration. ${ }^{42}$ PDmax for both treatment groups was similar and was significantly better than placebo. RU $10 \mathrm{mg}$ produced a greater reduction than placebo in the severity of each of five symptoms, with statistically significant differences found for sneezing, itchy eyes and itchy nose. On the other hand the difference between ebastine and placebo was significant only for sneezing and itchy nose. The investigator's impression was that only RU showed statistically significant improvements over placebo.

A similar trial was performed comparing two doses of $\mathrm{RU}$ (10 and 20mg), cetirizine $10 \mathrm{mg}$ and placebo in patients suffering from PAR. ${ }^{26}$ PDmax scores recorded in all three treatment groups were significantly higher than in the placebo group ( $p<0.0001)$. The best value was reported with RU $20 \mathrm{mg}$ in comparison with placebo $(p<0.0001), R U 10 \mathrm{mg}$ and cetirizine $10 \mathrm{mg}(43 \%)$. Improvements were also superior to placebo $(p<0.01)$. There was no significant difference in the pair-wise comparison between the three active treatment groups. Patients treated with RU 10 and $20 \mathrm{mg}$ as well as cetirizine $10 \mathrm{mg}$ had lower scores for the evaluated symptoms than patients receiving placebo. Individual symptom scores for active treatments were better than with placebo $(p<0.001)$. Differences reached a higher level of significance in all four nasal symptoms (including nasal obstruction) and near to significance $(p=0.057)$ in conjunctival itching. Investigator rating of overall efficacy was similar to that of patients. Both reported active treatment to be more effective than placebo at the second and last week of therapy.

Recently, a study was conducted to assess the efficacy of RU in moderate to severe $A R^{63}$ Patients were randomised to treatment with either RU $10 \mathrm{mg}$, cetirizine $10 \mathrm{mg}$ or placebo for 12 weeks. The primary efficacy endpoint was the 12-week average change from baseline of the patients' Total Symptom Score (Tss). Rupatadine, but not cetirizine, reduced the baseline Tss statistically more than placebo $(p=0.008)$. Study treatments were well tolerated and no relevant ECG changes or symptomatic lab abnormalities were evidenced throughout the study.

\section{Post-ARIA pooled analysis of efficacy studies in allergic rhinitis}

An exploratory analysis was performed to assess the efficacy of $\mathrm{RU}$, pooling data from pivotal clinical studies developed before the ARIA document. ${ }^{64,65,66}$ The existing ten studies, using the seasonal and perennial rhinitis classifications, were re-examined 
Figure 2. Pooled analysis of efficacy of Rupatadine 10 and $20 \mathrm{mg}$ in comparison to placebo. Data obtained from seven clinical trials expressed as percentage of reduction from baseline of total symptoms score during the entire double blinded period

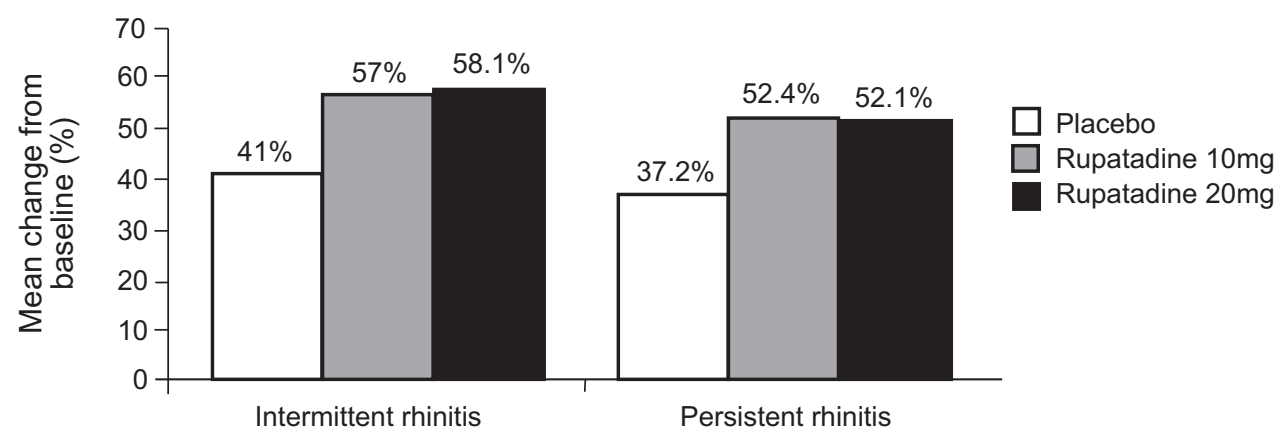

\section{Key Messages}

Rupatadine is a once-daily non-sedative, selective, longacting $\mathrm{H} 1$ anti-histamine with antagonistic PAF effects. Rupatadine significantly improves nasal symptoms in patients with allergic rhinitis. It has a good safety profile devoid of arrythmogenic effects and several interactions. Rupatadine does not affect driving performance. These properties make rupatadine a suitable first-line anti-histamine for the treatment of allergic rhinitis.

to assess whether the AR characteristics of patients enrolled in these studies met the ARIA classification criteria. ${ }^{65}$ Intermittent rhinitis was defined when symptoms were present for less than four weeks and persistent when symptoms lasted for more than four weeks.

A total of seven studies were included in the analysis, involving a population of 560 patients with intermittent, and 708 with persistent, allergic rhinitis. A summary is presented in Figure 2. Both doses (10 and 20mg) of RU caused high and significant reduction of Tss $(p<0.001)$ in comparison with placebo in both intermittent and persistent rhinitis. This study confirms that these doses of rupatadine - 10mg and $20 \mathrm{mg}-$ are effective in the control of rhinitis symptoms using the ARIA rhinitis criteria.

\section{Conclusions}

Rupatadine (RU) is a once-daily non-sedative, selective, longacting $\mathrm{H} 1$ anti-histamine with antagonistic PAF effects through its interaction with specific receptors. In the treatment of allergic rhinitis (AR), RU $10 \mathrm{mg}$ and $20 \mathrm{mg}$ per day is better than placebo and at least as effective as ebastine, cetirizine, loratadine and desloratadine, with a possible faster effect than cetirizine. RU significantly improves nasal symptoms in patients with AR. It has a good safety profile devoid of arrythmogenic effects, and has no interactions with azithromycin, fluoxetine and lorazepam, though co-administration with erythromycin, ketoconazole or grapefruit should be avoided. It has been safely administered for over one year. Rupatadine does not affect driving performance. Adverse events related to RU have been similar to those with comparators. These properties make RU a suitable first-line anti-histamine for the treatment of AR.

\section{Conflicts of interest}

None declared.

\section{References}

1. Skoner DP. Allergic rhinitis: definition, epidemiology, pathophysiology, detection, and diagnosis. J Allergy Clin Immunol 2001;108:S2-8. http://dx.doi.org/10.1067/mai.2001.115569

2. Boulay ME, Boulet LP. The relationships between atopy, rhinitis and asthma: pathophysiological considerations. Mechanisms of allergy and adult asthma. Curr Opin Allergy Clin Immunol 2003;3:51-5. http://dx.doi.org/10.1097/00130832-200302000-00009

3. Howarth PH. The cellular basis for allergic rhinitis. Allergy 1995;50:6-10. http://dx.doi.org/10.1111/j.1398-9995.1995.tb02734.x

4. Alfaro $\mathrm{V}$. Role of histamine and platelet-activating factor in allergic rhinitis. $J$ Physiol Biochem 2004;60:101-11.

5. Hunt DL, McKibbon KA. Locating and appraising systematic reviews. Ann Intern Med 1997; 126:532-8.

6. Albert DH, Malo PE, Tapang $\mathrm{P}$, et al. The role of platelet-activating factor (PAF) and the efficacy of ABT-491, a highly potent and selective PAF antagonist, in experimental allergic rhinitis. J Pharmacol Exp Ther 1998;284:83-8.

7. Albert DH, Tapang P, Morgan DW, et al. ABT-491, a highly potent and selective PAF antagonist, inhibits nasal vascular permeability associated with experimental allergic rhinitis in Brown Norway rats. Inflamm Res 1997;46:1334. http://dx.doi.org/10.1007/s000110050141

8. Yamada Y, Yokota M. Roles of plasma platelet-activating factor acetylhydrolase in allergic, inflammatory, and atherosclerotic diseases. Jpn Cir J 1998;62:328335. http://dx.doi.org/10.1253/jcj.62.328

9. American Academy of Allergy, Asthma and Immunology. The Allergy Report. Allergy Report Task Force with chairs Harold S. Nelson, MD, and Gary S. Rachelefsky, MD. Vol. 2: Diseases of the Atopic Diathesis. Milwaukee, WI: AAAAI, 6, 2000.

10. Misawa M, Iwamura S. Platelet-activating factor (PAF)-induced rhinitis and involvement of PAF in allergic rhinitis in guinea pigs. Jpn J Pharmacol 
1990;54:217-26. http://dx.doi.org/10.1254/jjp.54.217

11. Miadonna A, Tedeschi A, Arnoux B, Sala A, Zanussi C, Benveniste J. Evidence of PAF-acether metabolic pathway activation in antigen challenge of upper respiratory airways. Am Rev Respir Dis 1989;140:142-7.

12. Shirasaki $H$, Asakura K. Detection of platelet-activating factor in nasal lavage fluid from patients with pollinosis and experimental animals with nasal allergy. Nippon Jibiinkoka Gakkai Kaiho 1990;93:420-7.

13. Shirasaki H, Seki N, Kikuchi M, et al. Expression and localization of plateletactivating factor receptor in human nasal mucosa. Ann Allergy Asthma Immunol 2005;95:190-6.

14. Mustafa SB, Pearce FL. Histamine secretion from mast cells stimulated with platelet activating factor. Inflamm Res 1992;36:C265-7.

15. Snyder F. Metabolic processing of PAF. Clin Rev Allergy 1994;12:309-27.

16. Turner PJ, Dear JW, Foreman JC. Involvement of kinins in hyperresponsiveness induced by platelet activating factor in the human nasal airway. $\mathrm{Br} J$ Pharmacol 2000;129:525-32. http://dx.doi.org/10.1038/sj.bjp.0703095

17. Bartemes KR, McKinney S, Gleich GJ, Kita H. Endogenous Platelet-Activating Factor Is Critically Involved in Effector Functions of Eosinophils Stimulated with IL-5 or IgG. J Immunol 1999;162:2982-9.

18. Narita S, Asakura K. The effects of anti-PAF and other agents on the nasa symptoms in sensitized guinea pigs. Auris Nasus Larynx 1993;20:175-83.

19. Merlos M, Giral M, Balsa D, et al. Rupatadine, a new potent, orally active dual antagonist of histamine and platelet-activating factor (PAF). J Pharmacol Exp Ther 1997;280:114-21

20. Townley RG, Okada C. Use of cetirizine to investigate non-H1 effects of secondgeneration antihistamines. Ann Allergy 1992;68:190-6.

21. Eda R, Sugiyama H, Hopp RJ, Bewtra AK, Townley RG. Effect of loratadine on human eosinophil function in vitro. Ann Allergy 1993;71:373-8.

22. Izquierdo I, Nieto C, Ramis J, Cooper M, Dewland P. Forn J. Pharmacokinetic and dose linearity of rupatadine fumarate in healthy volunteers. Meth Find Exp Clin Pharmacol 1997;19:189.

23. Keam SJ, Plosker GL. Rupatadine: A review of its use in the management of allergic disorders. Drugs 2007;67:457-74.

24. Bartra J, Valero AL, Cuvillo DA, et al. Interactions of the $\mathrm{H} 1$ antihistamines. J Investig Allergol Clin Immunol 2006;16:29-36.

25. Cuvillo DA, Mullol J, Bartra J, et al. Comparative pharmacology of the $\mathrm{H} 1$ antihistamines. J Investig Allergol Clin Immunol 2006;16:3-12.

26. Izquierdo I, Merlos M, Garcia-Rafanell J. Rupatadine. A new selective histamine $\mathrm{H} 1$ receptor and platelet-activating factor (PAF) antagonist. Drugs Today 2003;39:451-68. http://dx.doi.org/10.1358/dot.2003.39.6.799450

27. Kane GC, Lipsky JJ. Drug-grapefruit juice interactions. Mayo Clin Proc 2000;75 933-42. http://dx.doi.org/10.4065/75.9.933

28. Solans A, Carbó M, Peña J, Nadal T, Izquierdo I, Merlos M. Influence of food on the oral bioavailability of rupatadine tablets in healthy volunteers: A singledose, randomized, open-label, two-way crossover study. Clinical Therapeutics 2007;29:900-08. http://dx.doi.org/10.1016/j.clinthera.2007.05.004

29. Queralt M, Brazís P, Merlos M, De Mora F, Puigdemont A. In vitro inhibitory effect of rupatadine on histamine and TNF-a release from dispersed canine skin mast cells and the human mast cell line HMC-1. Inflamm Res 2000;49:355-60. http://dx.doi.org/10.1007/PL00000216

30. Barron S, Ramis I, Garcia Rafanell J, Merlos M. Inhibitory activity of rupatadine on pro-inflamatory cytokine production, relationship with binding affinity. Methods Find Clin Pharmacol 2005;27:161

31. Hüther KJ, Renftle G, Barraud N, Burke JT, Koch-Weser J. Inhibitory activity of terfenadine on histamine-induced skin wheals in man. Eur J Clin Pharmacol 1977;12:195-9. http://dx.doi.org/10.1007/BF00609860

32. Bateman DN, Chapman PH, Rawlins MD. The effects of astemizole on histamine-induced weal and flare. Eur J Clin Pharmacol 1983;25:547-51. http://dx.doi.org/10.1007/BF00542126

33. Barbanoj MJ , García-Gea C, Morte A, Izquierdo I, Pérez I, Jané F. Central and peripheral evaluation of rupatadine, a new antihistamine/platelet-activating factor antagonist, at different doses in healthy volunteers. Neuropsychobiology 2004;50:311-21. http://dx.doi.org/10.1159/000080959

34. Queralt M, Merlos M, Giral M, Puigdemont A. Dual effect of a new compound, rupatadine, on edema induced by platelet-activating factor and histamine in dogs: Comparison with antihistamines and PAF antagonists. Drug Development Research 1998;39:12-8. http://dx.doi.org/10.1002/(SICI) 1098-2299(19960901)39:1<12::AID-DDR2>3.0.CO;2-N

35. Merlos M, Ferrando R, Giral M, Ramis I, Forn J. Effect of rupatadine on experimental conjunctivitis in guinea pigs: macroscopic evaluation of ocular lesions. Allergy Clin Immunol 2001;107:s310.

36. Queralt M, Brazís P, Merlos M, Puigdemont A. Inhibitory effects of rupatadine on mast cell histamine release and skin wheal development induced by Ascaris suum in hypersensitive dogs. Drug Development Research 1998:44:49-55. http://dx.doi.org/10.1002/(SICI)1098-2299(199806/07)44:2/3<49::AIDDDR1>3.0.CO;2-A

37. Merlos M, Ramis I, Balsa D, Queralt M, Brazis P, Puigdemont A. Inhibitory effect of rupatadine on TNF alpha release from human monocytes and mast cell line MHC-1. Allergy Clin Immunol 2000;105:s62. http://dx.doi.org/10.1016/ S0091-6749 (00)90622-5

38. García-Rafanell J, Forn J, Merlos M, Giral M, Balsa D, Ferrando R. Rupatadine inhibits the eosinophil recruitment in BAL fluid of ovalbumin-sensitized guinea pigs. J Allergy Clin Immunol 1998;101:S 218.

39. Warringa RA, Mengelers HJ, Kuijper PH, Raaijmakers JA, Bruijnzeel PL, Koenderman L. In vivo priming of platelet-activating factor-induced eosinophil chemotaxis in allergic asthmatic individuals. Blood 1992;79:1836-41.

40. Kurihara K, Wardlaw AJ, Moqbel R, Kay AB. Inhibition of platelet-activating factor (PAF)-induced chemotaxis and PAF binding to human eosinophils and neutrophils by the specific ginkgolide-derived PAF antagonist, BN 52021. A Allergy Clin Immunol 1989;83:83-90. http://dx.doi.org/10.1016/00916749(89)90480-6

41. Barr'on S, Ramis I, Merlos M. Effect of rupatadine on lymphocyte cytokine production. Allergy Clin Immunol Int 2005;Suppl.1:427.

42. Picado C. Rupatadine: pharmacological profile and its use in the treatment of allergic disorders. Expert Opin Pharmacother 2006;7:1989-2001. http://dx.doi.org/10.1517/14656566.7.14.1989

43. Valero A, de la Torre F, Castillo JA, Rivas $P$, et al. Safety of rupatadine administered over a period of 1 year in the treatment of persistent allergic rhinitis. Drug Safety 2009;32(1):33-42.

44. Giral M, Merlos M, Balsa D, Ferrando R, Garcia-Rafanell J, Forn J. Effects of rupatadine on cardiovascular profile in rats and guinea pigs. Comparison with other non-sedating antihistamines. Allergy 1997;52:44-5.

45. Berul Cl, Morad M. Regulation of Potassium Channels by Nonsedating Antihistamines. Circulation 1995;91:2220-5.

46. Rampe D, Wible B, Brown AM, Dage RC. Effects of terfenadine and its metabolites on a delayed rectifier $\mathrm{K}+$ channel cloned from human heart. $\mathrm{Mol}$ Pharmacol 1993;44:1240-5.

47. Wang Z, Fermini B, Nattel S. Sustained depolarization-induced outward current in human atrial myocytes. Evidence for a novel delayed rectifier $\mathrm{K}+$ current similar to Kv1.5 cloned channel currents. Circulation Research 1993;73:106176.

48. Caballero R, Valenzuela C, Longobardo M, Tamargo J, Delpón E. Effects of rupatadine, a new dual antagonist of histamine and platelet-activating factor receptors, on human cardiac Kv1.5 channels. Br J Pharmacol 1999; 128:1071-81. http://dx.doi.org/10.1038/sj.bjp.0702890

49. García rafanell J. Rupatadine fumarate. Drugs Fut 1996;21:1032-6.

50. Hove-Madsen L, Llach A, Molina CE, et al. The proarrhythmic antihistaminic drug terfenadine increases spontaneous calcium release in human atrial myocytes. Eur J Pharmacol 2006;553:215-21. http://dx.doi.org/10.1016/ j.ejphar.2006.09.023 


\section{S Katiyar and S Prakash}

51. Patterson S, Agin M, Anziano R, et al. Investigating Drug-Induced QT and QTC Prolongation in the Clinic: A Review of Statistical Design and Analysis Considerations: Report from the Pharmaceutical Research and Manufacturers of America QT Statistics Expert Team. Drug Information Journal 2005;39:24366.

52. Donado E, Garcia O, Perez I et al. Cardiac safety of rupatadine according to the new ICH guideline: A thorough QT/QTc study. Paper presented at: EAACI 2006 $\mathrm{XXV}$ congress of the European academy of allergology and clinical immunology; 2006 June 10-14; Vienna, Austria.

53. Barbanoj MJ, García-Gea C, Antonijoan R, et al. Evaluation of the cognitive, psychomotor and pharmacokinetic profiles of rupatadine, hydroxyzine and cetirizine, in combination with alcohol, in healthy volunteers. Hum Psychopharmacol 2006;21:13-26. http://dx.doi.org/10.1002/hup.741

54. Vuurman E, Theunissen E, van Oers A, van Leeuwen C, Jolles J. Lack of effects between rupatadine $10 \mathrm{mg}$ and placebo on actual driving performance of healthy volunteers. Hum Psychopharmacol 2007;22:289-97. http://dx.doi.org/10.1002/ hup.856

55. Jáuregui I, Mullol J, Bartra J, et al. H1 antihistamines: psychomotor performance and driving. J Investig Allergol Clin Immunol 2006;16:37-44.

56. Bronsky E, Boggs P, Findlay S, et al. Comparative efficacy and safety of a oncedaily loratadine-pseudoephedrine combination versus its components alone and placebo in the management of seasonal allergic rhinitis. J Allergy Clin Immunol 1995;96:139-47. http://dx.doi.org/10.1016/S0091-6749(95)70001-3

57. Jobst S, van den Wijngaart W, Schubert A, van de Venne H. Assessment of the efficacy and safety of three dose levels of cetirizine given once daily in children with perennial allergic rhinitis. Allergy 1994;49:598-604 http://dx.doi.org/10.1111/j.1398-9995.1994.tb00125.x

58. Izquierdo I, Paredes I, Lurigados C, Sospedra E, Cooper M, Thomas H. A dose ranging study of rupatadine fumarate in patients with seasonal allergic rhinitis. Allergy 2000;55:275

59. Guadaño EM, Serra-Batlles J, Meseguer J, et al. Rupatadine $10 \mathrm{mg}$ and ebastine $10 \mathrm{mg}$ in seasonal allergic rhinitis: a comparison study. Allergy 2004;59:766-71. http://dx.doi.org/10.1111/j.1398-9995.2004.00576.x

60. Martínez-Cócera C, De Molina M, Martí-Guadaño E, et al. Rupatadine 10 mg and cetirizine $10 \mathrm{mg}$ in seasonal allergic rhinitis: A randomised, double-blind parallel study. J Invest Allergol Clin Immunol 2005;15:22-9.

61. Saint-Martin F, Dumur JP, Pérez I, Izquierdo I. A randomized, double-blind, parallel-group study, comparing the efficacy and safety of rupatadine (20 and $10 \mathrm{mg}$ ), a new PAF and $\mathrm{H} 1$ receptor-specific histamine antagonist, to loratadine $10 \mathrm{mg}$ in the treatment of seasonal allergic rhinitis. J Invest Allergol Clin Immunol 2004;14:34-40.

62. Stuebner P, Horak F, Zieglmayer R, et al. Effects of rupatadine vs placebo on allergen-induced symptoms in patients exposed to aeroallergens in the Vienna Challenge Chamber. Ann Allergy Asthma Immunol 2006;96:37-44

63. Fantin S, Maspero J, Bisbal C, Agache I, Donado E, Borja J, Mola O, Izquierdo I; international Rupatadine study group. A 12-week placebo-controlled study of rupatadine $10 \mathrm{mg}$ once daily compared with cetirizine $10 \mathrm{mg}$ once daily, in the treatment of persistent allergic rhinitis. Allergy 2008;63:924-31.

64. Perez I, Villa M, De la Cruz G, Izquierdo I. Rupatadine in allergic rhinitis: Pooled analysis of efficacy data. Allergy 2002;57:245.

65. Bousquet J, Van Cauwenberge P, Khaltaev N. Allergic Rhinitis and its Impact on Asthma (ARIA) In collaboration with the World Health Organization. Allergy 2002;57:841-55

66. Izquierdo I, Valero A, García O, Pérez I, Mullol J, Van Cauwenberge P. Clinical efficacy of rupatadine in allergic rhinitis under ARIA criteria: pooled analysis. Allergy Clin Immunol Int 2005;1:271.

\section{Available online at http://www.thepcrj.org}

